\title{
Management of deep carious lesions and pulps exposed during carious tissue removal in adults : a questionnaire study among dentists in Finland
}

\section{Croft, Katri}

2019-03

Croft , K , Kervanto-Seppälä , S , Stangvaltaite , L \& Kerosuo , E 2019 , ' Management of deep carious lesions and pulps exposed during carious tissue removal in adults : a questionnaire study among dentists in Finland ' , Clinical Oral Investigations, vol. 23 , no. 3 , pp. 1271-1280 . https://doi.org/10.1007/s00784-018-2556-1

http://hdl.handle.net/10138/303578

https://doi.org/10.1007/s00784-018-2556-1

publishedVersion

Downloaded from Helda, University of Helsinki institutional repository.

This is an electronic reprint of the original article.

This reprint may differ from the original in pagination and typographic detail.

Please cite the original version. 


\title{
Management of deep carious lesions and pulps exposed during carious tissue removal in adults: a questionnaire study among dentists in Finland
}

\author{
Katri Croft ${ }^{1}$ (D) Sari Kervanto-Seppälä ${ }^{1,2} \cdot$ Lina Stangvaltaite $^{3} \cdot$ Eero Kerosuo $^{3}$
}

Received: 17 March 2018 / Accepted: 2 July 2018 / Published online: 9 July 2018

(C) Springer-Verlag GmbH Germany, part of Springer Nature 2018

\begin{abstract}
Objectives To find out which management methods are preferred by dentists in Finland for a deep carious lesion or a pulp exposed during carious tissue removal in adult patients.

Materials and methods An electronic questionnaire consisting of 25 questions was sent to 1000 randomly sampled dentists in Finland. The response rate was $32 \%$.

Results Less invasive excavation strategies (stepwise or selective removal) were preferred by $64 \%$ for an asymptomatic deep lesion, while $34 \%$ chose nonselective removal to hard dentine. In the presence of an asymptomatic pulpal exposure, vital pulp therapy was preferred, as $71 \%$ of the respondents chose direct pulp capping (DPC) or partial pulpotomy, compared to root canal treatment (26\%). Mineral trioxide aggregate (MTA) and calcium hydroxide-based materials were both chosen by $40 \%$ for vital pulp therapy. In the management of a deep carious lesion, less invasive excavation strategies were significantly associated with having clinical guidelines vs. no guidelines at the practice [odds ratio (OR) 3.5, confidence interval (CI) 1.4-9.0]. MTA was favored over other DPC materials significantly more often by those who had attended continuing education courses during the last 3 years (OR 2.8, CI 1.2-6.5).

Conclusions Less invasive management strategies have been adopted into clinical practice by the majority of dentists in Finland. There is a need to encourage the use of MTA in the case of a pulpal exposure.

Clinical relevance The results of this study can be utilized in continuing education, to raise awareness of management strategies supported by present scientific evidence.
\end{abstract}

Keywords Deep carious lesion $\cdot$ Carious exposure $\cdot$ Caries removal $\cdot$ Direct pulp capping $\cdot$ MTA

\section{Introduction}

The prevalence of dental caries has declined significantly in Western countries in the latter half of the twentieth century [1].

Electronic supplementary material The online version of this article (https://doi.org/10.1007/s00784-018-2556-1) contains supplementary material, which is available to authorized users.

Katri Croft

katri.croft@helsinki.fi

1 Institute of Dentistry, Department of Oral and Maxillofacial Diseases, University of Helsinki, (Mannerheimintie 172), PO Box 41, 00014 Helsinki, Finland

2 Vantaa Health Center, Jönsaksentie 4, 01600 Vantaa, Finland

3 Department of Clinical Dentistry, Faculty of Health Sciences, UiT The Arctic University of Norway, Postboks 6050 Langnes, 9037 Tromsø, Norway
Despite this decline, $31 \%$ of adult patients in Finland had at least one untreated dentine carious lesion according to a study carried out in 2000-2001; $41 \%$ of these patients reported to seek dental care only when experiencing symptoms, which might indicate they have a deep carious lesion [2]. The prevalence of deep carious lesions remains a challenge to the dental profession. Despite the free-of-charge dental health care, one quarter of 18-year-olds in Northern Norway had at least one molar with a treated or untreated deep carious lesion [3].

Traditionally, dentists have aimed at removing all soft and demineralized dentine (nonselective removal to hard dentine) before placing a restoration $[4,5]$. When excavating a deep carious lesion, this technique often results in a pulpal exposure [6]. In order to avoid a pulpal exposure, other management methods have been suggested. In stepwise removal, all carious dentine is removed from the peripheral walls of the cavity, while leaving some carious dentine over the pulp [7]. The cavity is then temporarily sealed, to enable the formation of 
tertiary dentine and remineralization of the demineralized dentine. At re-entry the eventual remaining soft dentine is excavated before placing the permanent restoration. This technique has been shown to significantly reduce the risk of a pulpal exposure: stepwise removal resulted in an exposure in $18 \%$ of cases, compared with $29 \%$ in the nonselective removal group [6]. Recently, selective removal to soft dentine, where carious dentine is left on the pulpal wall under the permanent restoration, has shown higher success rate compared to stepwise removal, thus challenging the need for re-entry [8-10].

There are several management options, if a deep carious lesion results in a pulpal exposure during carious tissue removal. Until recently, pulpectomy followed by root canal treatment has been the method of choice for an adult patient, as it has provided the most predictable outcome with success rates between 86 and 93\% [11]. However, epidemiological studies have revealed that the prevalence of periapical lesions, following root canal treatment, is in reality higher than failure rates of well-designed clinical studies [12]. Further, when CBCT was used to evaluate the outcome of root canal treatment, apical periodontitis was detected significantly more often than in periapical radiographs [13]. Vital pulp has several important functions, including tooth sensitivity, proprioceptive function, and protective damping effect, which are lost during root canal treatment $[14,15]$. Root canal treatment is also expensive and time-consuming and weakens the tooth, increasing the risk of fractures [16]. Therefore, pulpal vitality should be maintained whenever possible.

Vital pulp therapies aiming at maintaining pulpal vitality include the following: (i) direct pulp capping (DPC); (ii) partial pulpotomy (PP); and (iii) coronal pulpotomy. When success was defined as a vital, asymptomatic tooth without apical radiolucency, extremely low long-term success was reported after DPC with calcium hydroxide $(\mathrm{CH})$ in a retrospective study [17]. In a Scandinavian multicenter randomized trial, the success rate was less than $35 \%$ for DPC with $\mathrm{CH}$ in adults after 1-year follow-up [6]. In a case series study, Bogen and co-workers showed excellent results, also in adults, when mineral trioxide aggregate (MTA) was used as a DPC material over pulps exposed during carious tissue removal in permanent molars [18]. Coronal pulpotomy has also been suggested as an alternative for root canal treatment for cariously exposed permanent teeth with closed apices, but the evidence is limited [19].

When this questionnaire study was launched, there were neither international nor national guidelines in Finland for the management of deep carious lesions or pulps exposed during carious tissue removal. After collecting the data for this questionnaire study, the International Caries Consensus Collaboration presented recommendations for carious tissue removal [20]. These recommendations emphasize the importance of preserving pulpal vitality. They recommend selective removal of carious tissue to soft dentine or alternatively stepwise removal in deep carious lesions. Less invasive approaches for the removal of carious tissue have not been widely adopted into clinical practice according to previous questionnaire studies. For example, nonselective removal to hard dentine was favored by more than $50 \%$ of dentists for the management of deep carious lesions in the USA, Brazil, and Germany [21-23].

The aim of this study was to investigate which management methods are preferred by the dentists in Finland for a deep carious lesion or for a pulp exposed during carious tissue removal in adults and how symptoms and the respondent's background influence these decisions.

\section{Materials and methods}

The present questionnaire study was carried out in Finland during spring 2016, using the e-form of the University of Helsinki. A simple random sample of 1000 dentists $(22 \%$ of dentists in Finland) was selected from the register of the Finnish Dental Association. The Finnish Dental Association only provided the email addresses of the dentists in the sample, so the researchers did not have access to any personal information. The email addresses were uploaded to the eform system of the University of Helsinki. The system then automatically provided each recipient with a personal username and a password, to access the e-form only once. When the invitation to partake in the survey was sent out, the recipients were contacted by email, which included a cover letter explaining the purpose of the study. The username was registered when the respondent signed into the e-form, which prevented completing the questionnaire more than once. In addition, this method enabled targeting only nonrespondents with reminder emails. The researchers were not provided with the information to connect email addresses with usernames, so answering the e-form took place anonymously and voluntarily.

A two-phase pilot study was conducted before sending out the final questionnaire. At the first stage, the content validity was tested by ten dentists who were either clinical teachers or experienced clinicians. Internal consistency (like Cronbach's alpha) could not be calculated for this questionnaire due to the type of questions [24]. After evaluating the responses, the questionnaire was modified and transferred into the e-form. The usability and functionality of the e-form was then tested again by nine dentists, including a senior university lecturer, clinical teachers, and general practitioners from the public and private sector. Based on the feedback, the final questionnaire was completed and sent out. Three successive reminder emails were sent to the non-respondents after every 2 weeks. After 8 weeks the survey was closed.

The questionnaire comprised 25 questions. A schematic drawing of a deep carious lesion (Fig. 1) was included. The 
Fig. 1 A schematic drawing of a bitewing radiograph presenting a permanent upper right first molar and the three different symptom scenarios given in the questionnaire

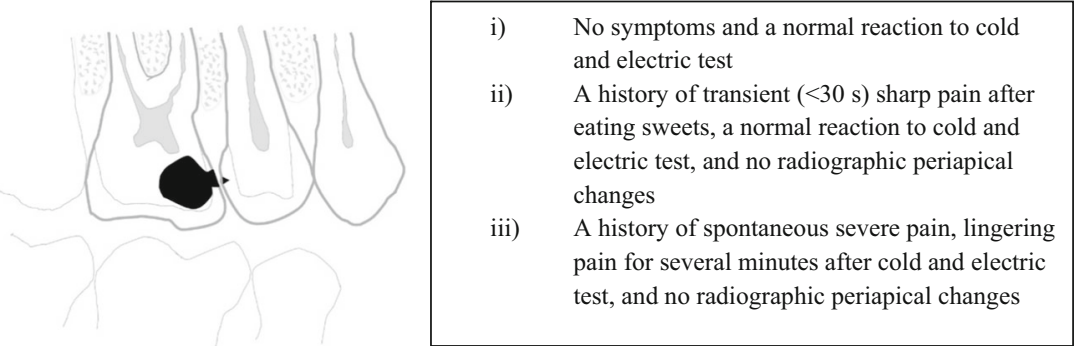

case presented a 30-year-old female patient, who had a deep carious lesion in the permanent upper right first molar. The case was presented in three different symptom scenarios: (i) asymptomatic, or symptoms referring to either (ii) reversible (no lingering pain but transient pain lasting max. $30 \mathrm{~s}$ ); or (iii) irreversible (lingering pain for several minutes) pulpitis. The five management options given were (i) total excavation (nonselective removal to hard dentine); (ii) stepwise excavation (stepwise removal); (iii) indirect pulp capping (selective removal); (iv) coronal pulpotomy; and (v) pulpectomy followed by root canal treatment.

Another set of questions concerned the management of an eventual pulpal exposure that had emerged during the carious tissue removal in the abovementioned patient. The same three symptom scenarios were presented and the respondent was asked to choose from the following four management options for each of them: (i) direct pulp capping (DPC); (ii) partial pulpotomy (PP); (iii) coronal pulpotomy; and (iv) pulpectomy followed by root canal treatment. As there is variation regarding the terminology, all management options were defined in the questionnaire to avoid misunderstanding. The dentists were also asked to indicate their preferred method and criteria for removal of carious tissue, the choice of material for a deep carious lesion and for a pulp exposed during carious tissue removal, the use of periapical radiographs and rubber dam, and the main reasons behind the management decisions. In addition, demographic and other background information about the respondents were collected.

The e-form of the University of Helsinki transferred the responses into a SPSS file. The data was analyzed statistically using SPSS version 24 (IBM, Somers, New York, NY). Chisquare test was used to study the demographic differences between respondents and dentists nationwide. Chi-square test was also used to compare the demographic information and management decisions of the early respondents (those who responded after the first emailing round) and later respondents (those who responded after a reminder email). Binary multivariable logistic regression analysis was used to study the background characteristics of the respondents related to two outcomes: (i) the choice of less invasive approach in the case of a deep carious lesion and (ii) the use of MTA as the material for DPC, PP, or coronal pulpotomy. Asymptomatic and reversible pulpitis scenarios were pooled for the analysis of less invasive approach for the management of a deep carious lesion. The use of MTA was based on a separate question and included only those who had chosen to perform DPC, PP, or coronal pulpotomy after a pulpal exposure.

Initially, $2 \times 2$ contingency tables were used to study the relation of the outcome and background characteristic variables. If the Pearson chi-square value was significant, the background characteristic variable was chosen as an independent variable for the binary multivariable logistic regression analysis. Through this, odds ratios (OR) and their confidence intervals $(\mathrm{CI})$ were calculated. The level of significance was set at $p<0.05$.

As the dentists were asked only about their general management preferences and no patient information was included, an ethical approval was considered unnecessary.

\section{Results}

Out of a thousand emails sent out, 21 were returned because of an invalid email address or "out of office" autoreply. Another 13 dentists responded with an email informing they were no longer practicing operative dentistry or they were unable or unwilling to respond to the questionnaire. The total number of responses through the e-form was 349 . The first question was set to find out whether the respondent practiced operative dentistry. Only those who had indicated to practice operative dentistry at least sporadically and had completed the questionnaire were included in the final analysis. The total number of completed questionnaires was 323 , giving a final response rate of $32 \%$.

As the Finnish Dental Association only gave email addresses of the dentists, no background information regarding the non-respondents was available. However, compared to the dentists nationwide, there was an over-representation of female dentists $(p=0.016)$ and publicly employed dentists $(p=0.017)$ detected among the respondents, but no significant difference was found in the distribution of age groups $(<$ 45 years vs. $\geq 45$ years, $p=0.207$ ). No systematic difference between the early respondents and the later respondents was found in the demographic information (Table 1) or the key management decisions $(p>0.05)$. 
Table 1 Background information of respondents vs. Finnish dentists in general and early vs. later respondents

Background variable

Gender

\section{Gender}

\begin{tabular}{|c|c|c|c|c|c|c|}
\hline Male & $80(25)$ & $1395(31)$ & $p=0.016^{* 5}$ & $37(25)$ & $43(25)$ & $p=0.948$, N.S. $^{6}$ \\
\hline Female & $240(75)$ & 3105 (69) & & $112(75)$ & $128(75)$ & \\
\hline Total $n$ & $320(100)$ & $4500(100)$ & & $149(100)$ & $171(100)$ & \\
\hline
\end{tabular}

Age

$<45$ years
$\geq 45$ years
Total $n$

Primary sector of practice

$\begin{array}{ll}\text { Private } & 112(35) \\ \text { Public } & 205(65) \\ \text { Total } n & 317(100) \\ \text { ation } & \\ 1970-1990 & 145(48) \\ 1991-2015 & 160(52) \\ \text { Total } n & 305(100)\end{array}$

University of graduation

$\begin{array}{ll}\text { Helsinki } & 101(32) \\ \text { Turku } & 93(29) \\ \text { Kuopio } & 28(9) \\ \text { Oulu } & 74(23) \\ \text { Abroad } & 22(7) \\ \text { Total } n & 318(100)\end{array}$

Location of practice

$\begin{array}{ll}\text { Helsinki region } & 105(33) \\ \text { Turku region } & 49(15) \\ \text { Kuopio region } & 20(6) \\ \text { Oulu region } & 25(8) \\ \text { Other } & 122(38) \\ \text { Total } n & 321(100)\end{array}$

Agreed local clinical guidelines

$\begin{array}{ll}\text { Yes } & 43(13) \\ \text { No } & 244(76) \\ \text { Not sure } & 33(10) \\ \text { Total } n & 320(100)\end{array}$

Position as the head of dental staff

$\begin{array}{ll}\text { Yes } & 74(24) \\ \text { No } & 240(76) \\ \text { Total } n & 314(100)\end{array}$

Continuing education courses in operative dentistry and endodontology through participation at the Finnish Dental Congress

$\begin{array}{ll}\text { Last } 12 \text { months } & 97(37) \\ \text { Last } 3 \text { years } & 107(41) \\ \text { Earlier } & 48(18) \\ \text { Never } & 11(4) \\ \text { Total } n & 263(100)\end{array}$

Continuing education courses in operative dentistry and endodontology by FDS $^{7}$
Last 12 months
$75(31)$
Last 3 years
$83(34)$

Early ${ }^{2}$ respondents, Later $^{3}$ respondents, $p$ value ${ }^{4}$ $n(\%) \quad n(\%)$

$\begin{array}{llll}1285(32) & p=0.207, \text { N.S. } & 55(37) & 59(34) \\ 2699(68) & & 95(63) & 113(66) \\ 3984(100) & & 150(100) & 172(100) \\ & & & \\ 1611(42) & p=0.017^{*} & 49(33) & 63(37) \\ 2255(58) & & 98(67) & 107(63) \\ 3866(100) & & 147(100) & 170(100)\end{array}$

$p=0.658$, N.S.

$p=0.489$, N.S.
Year of graduation
Respondents, Finnish dentists in general, $n(\%)$ 
Table 1 (continued)

\begin{tabular}{|c|c|c|c|c|c|}
\hline Background variable & $\begin{array}{l}\text { Respondents, } \\
n(\%)\end{array}$ & $\begin{array}{l}\text { Finnish dentists } \quad p \text { value }^{1} \\
\text { in general, } n(\%)\end{array}$ & $\begin{array}{l}\text { Early }{ }^{2} \text { respondents, } \\
n(\%)\end{array}$ & $\begin{array}{l}\text { Later }^{3} \text { respondents, } \\
n(\%)\end{array}$ & $p$ value $^{4}$ \\
\hline Earlier & $63(26)$ & & & & \\
\hline Never & $23(9)$ & & & & \\
\hline Total $n$ & $244(100)$ & & & & \\
\hline \multicolumn{6}{|c|}{ Other continuing education courses in operative dentistry and endodontology } \\
\hline Last 12 months & $131(50)$ & & & & \\
\hline Last 3 years & $81(31)$ & & & & \\
\hline Earlier & $32(12)$ & & & & \\
\hline Never & $19(7)$ & & & & \\
\hline Total $n$ & $263(100)$ & & & & \\
\hline \multicolumn{6}{|c|}{ Original international scientific articles read about minimal intervention in operative dentistry } \\
\hline Last 12 months & $27(10)$ & & & & \\
\hline Last 3 years & $49(18)$ & & & & \\
\hline Earlier & $77(28)$ & & & & \\
\hline Never & $127(45)$ & & & & \\
\hline Total $n$ & $280(100)$ & & & & \\
\hline \multicolumn{6}{|c|}{ Summaries of original scientific articles about minimal intervention in operative dentistry read in $\mathrm{FDJ}^{8}$} \\
\hline Last 12 months & $180(57)$ & & & & \\
\hline Last 3 years & $101(32)$ & & & & \\
\hline Earlier & $21(7)$ & & & & \\
\hline Never & $13(4)$ & & & & \\
\hline Total $n$ & $315(100)$ & & & & \\
\hline
\end{tabular}

${ }^{1}$ Chi-square test: respondents vs. Finnish dentists in general (the respondents subtracted from the nationwide figure)

${ }^{2}$ Early respondent: response after the first email

${ }^{3}$ Later respondent: response after one or several reminder emails

${ }^{4}$ Chi-square test: early vs. later respondent

$5 * p<0.05$

${ }^{6}$ N.S. non-significant

${ }^{7} F D S$ the Finnish Dental Society

${ }^{8} F D J$ the Finnish Dental Journal

When presented with an asymptomatic deep carious lesion, $64 \%$ of all respondents preferred less invasive excavation strategies (stepwise or selective removal), while $34 \%$ opted for nonselective removal to hard dentine. The respondents were more prone to choose less invasive management strategies $(77 \%)$ in the presence of symptoms of reversible pulpitis. In the case of a deep carious lesion, with no exposure and symptoms of irreversible pulpitis, $66 \%$ would perform root canal treatment (Table 2).

Vital pulp therapies (DPC or PP) were preferred by the majority $(71 \%)$ for the management of an asymptomatic pulpal exposure, while root canal treatment was chosen infrequently $(26 \%)$. If symptoms of reversible pulpitis were present, the distribution of management preferences was more equal between vital pulp therapies (52\%) and root canal treatment $(43 \%)$. Root canal treatment was the predominantly chosen method (94\%) in the presence of a pulpal exposure and symptoms of irreversible pulpitis
(Table 2). The choice of material for DPC, PP, or coronal pulpotomy was equally distributed between MTA (39\%) and calcium hydroxide-based materials (40\%). Biodentine was preferred by $19 \%$ and the remaining $2 \%$ chose zinc oxide eugenol or "other" material.

Chi-square statistics in $2 \times 2$ contingency tables were used to study the relation between the choice of less invasive excavation strategy for a deep carious lesion and the choice of MTA for pulp capping. There was no statistically significant association between these choices $(p=$ 0.308). Also, the relation between having locally agreed guidelines and (i) the primary sector of practice and (ii) the location of practice was studied, but no statistically significant association was found $(p=0.292$ and $p=$ 0.241 , respectively).

Having clinical guidelines at the practice for the management of a deep carious lesion resulted in less invasive approach in caries excavation $(\mathrm{OR}=3.5$, CI 1.4-9.0) (vs. no 
Table 2 Distribution of management decisions among the respondents in two clinical cases: a deep carious lesion and a pulp exposed during carious tissue removal. Both cases presented with three different scenarios based on preoperative pain: asymptomatic, reversible pulpitis, and irreversible pulpitis

\begin{tabular}{|c|c|c|c|}
\hline \multirow[t]{2}{*}{ Case/management decision } & \multicolumn{3}{|l|}{ Scenario } \\
\hline & $\begin{array}{l}\text { Asymptomatic, } \\
n(\%)\end{array}$ & $\begin{array}{l}\text { Reversible } \\
\text { pulpitis, } n(\%)\end{array}$ & $\begin{array}{l}\text { Irreversible } \\
\text { pulpitis, } n(\%)\end{array}$ \\
\hline \multicolumn{4}{|l|}{ Deep carious lesion } \\
\hline Nonselective removal to hard dentine & $111(34)$ & $60(19)$ & $15(5)$ \\
\hline Stepwise removal & $157(49)$ & $201(62)$ & $76(24)$ \\
\hline Selective removal & $50(16)$ & $49(15)$ & $6(2)$ \\
\hline Coronal pulpotomy & $0(0)$ & $1(0)$ & $8(3)$ \\
\hline Pulpectomy followed by root canal treatment & $1(0)$ & $3(1)$ & $213(66)$ \\
\hline Other $^{1}$ & $4(1)$ & $9(3)$ & $5(2)$ \\
\hline Total $n$ & $323(100)$ & $323(100)$ & $323(100)$ \\
\hline \multicolumn{4}{|l|}{ Pulp exposed during carious tissue removal } \\
\hline $\mathrm{DPC}^{2}$ & $208(65)$ & $134(42)$ & $8(3)$ \\
\hline $\mathrm{PP}^{3}$ & $19(6)$ & $33(10)$ & $6(2)$ \\
\hline Coronal pulpotomy & $4(1)$ & $8(3)$ & $2(1)$ \\
\hline Pulpectomy followed by root canal treatment & $85(26)$ & $139(43)$ & $304(94)$ \\
\hline Other $^{4}$ & $6(2)$ & $6(2)$ & $2(1)$ \\
\hline Total $n$ & $322(100)$ & $320(100)$ & $322(100)$ \\
\hline
\end{tabular}

clinical guidelines) according to binary multivariable regression analysis. Those who had graduated from the University of Helsinki or Turku chose stepwise or selective removal significantly more often $(\mathrm{OR}=2.8$, CI 1.5-5.0), than those who had graduated from other Finnish universities or from abroad. The preference of less invasive excavation strategies was also significantly associated with working in the public sector $(\mathrm{OR}=2.3$, CI 1.3-3.8) compared to working in the private sector (Table 3 ).

MTA was preferred over other pulp capping materials by those who had graduated since $1986(\mathrm{OR}=6.0$, CI 2.0-18.3) (vs. graduation between 1970 and 1985). It was also preferred by those who had attended continuing education courses in operative dentistry or endodontology by the Finnish Dental Society within the last 3 years $(\mathrm{OR}=2.8$, CI 1.2-6.5) (vs. earlier or never) (Table 3 ).

When asked about the most important reason behind the management decision for a deep carious lesion, 56\% stated they wanted to avoid a pulpal exposure if possible. After a pulp exposed during carious tissue removal, $68 \%$ expressed they wanted to avoid root canal treatment, if there was a possibility for the tooth to remain vital. The second most important reason behind the management preference, both in the case of a deep carious lesion and a pulp exposed during carious tissue removal, was the experience of good results with the preferred method, chosen by 34 and $38 \%$, respectively.

\section{Discussion}

The response rate of the present study was rather low (32\%), although it is comparable to recent questionnaire studies on the topic $(23-35 \%)[23,25,26]$. There were several attempts to increase the response rate, first by using a user-friendly electronic questionnaire and second by targeting the nonrespondents with several reminder emails.

The present sample was selected from the national register of dentists in Finland. This is in contrast to most questionnaire studies on the topic which have been regional, apart from two recent multinational questionnaire studies [21-23, 25-27]. A slight over-representation of female and publicly employed dentists was detected but the age distribution was similar in the present sample compared to dentists nationwide. When comparing the early and later respondents, no statistically significant difference was detected in the background information or management decisions, which is in line with the results of a previous questionnaire study [27]. Therefore, with some caution, conclusions can be made from the results of the present study regarding the management preferences of dentists in Finland.

It was acknowledged that at the time of the present study, there were no consensus recommendations for the terminology used for carious tissue removal. All management options were defined in the questionnaire, which left less room for interpretation. The exact diagnosis was not stated for each 
Table 3 Binary multivariable logistic regression analysis. Associations of the respondents' background characteristics on management decisions

\begin{tabular}{|c|c|c|c|c|}
\hline \multirow[b]{2}{*}{ Background variable ${ }^{4}$} & \multicolumn{2}{|c|}{$\begin{array}{l}\text { Less invasive management } \\
\text { method preferred for a deep } \\
\text { carious lesion (in asymptomatic } \\
\text { or reversible pulpitis scenario) }\end{array}$} & \multicolumn{2}{|c|}{$\begin{array}{l}\mathrm{MTA}^{1} \text { chosen for } \mathrm{DPC}^{2} \text { or } \\
\mathrm{PP}^{3} \text { or coronal pulpotomy } \\
\text { (based on a separate question } \\
\text { irrespective of symptom } \\
\text { scenario) }\end{array}$} \\
\hline & $\mathrm{OR}^{5}\left(95 \% \mathrm{CI}^{6}\right)$ & $p$ value & OR $(95 \% \mathrm{CI})$ & $p$ value \\
\hline Gender female (vs. male) & $1.2(0.7-2.1)$ & 0.591, N.S. $^{7}$ & $1.6(0.7-3.8)$ & 0.292 , N.S. \\
\hline Age $\geq 45$ years (vs. $<45$ years) & $1.2(0.7-2.2)$ & 0.435, N.S & $1.5(0.6-3.4)$ & 0.355 , N.S. \\
\hline Year of graduation 1986-2015 (vs. 1970-1985) & Not tested & & $6.0(2.0-18.3)$ & $0.002 * 8$ \\
\hline University of Helsinki or Turku (vs. other universities or abroad) & $2.8(1.5-5.0)$ & $0.001 *$ & Not tested & \\
\hline Primary sector of practice: public (vs. private) & $2.3(1.3-3.8)$ & $0.003 *$ & $1.2(0.6-2.7)$ & 0.600 , N.S. \\
\hline Location of practice: Helsinki or Turku (vs. others) & $1.2(0.7-2.2)$ & 0.552 , N.S. & $1.7(0.8-3.7)$ & 0.162 , N.S. \\
\hline Agreed local clinical guidelines (vs. no) ${ }^{9}$ & $3.5(1.4-9.0)$ & $0.008 *$ & Not tested & \\
\hline Scientific summaries read in $\mathrm{FDJ}^{10}$ within last 3 years (vs. not read) & $2.3(1.0-5.3)$ & 0.054, N.S. & $1.7(0.4-7.6)$ & 0.464 , N.S. \\
\hline Continuing education courses by FDS $^{11}$ within last 3 years (vs. earlier or never) & Not tested & & $2.8(1.2-6.5)$ & $0.014 *$ \\
\hline Other continuing education courses within last 3 years (vs. earlier or never) & Not tested & & $1.4(0.5-3.9)$ & 0.466 , N.S. \\
\hline
\end{tabular}

Background variables not included in the multivariable test ${ }^{12}$

Year of graduation 1986-2015 (vs. 1970-1985)

0.169, N.S.

University of Helsinki or Turku (vs. other universities or abroad)

0.089 , N.S.

Position as a head of dental staff (vs. no)

0.412, N.S.

0.874 , N.S.

Participation in the Finnish Dental Congress within last 3 years (vs. earlier or never)

0.763, N.S.

0.739 , N.S.

Continuing education courses by FDS within last 3 years (vs. earlier or never)

0.172, N.S.

Other continuing education courses within last 3 years (vs. earlier or never)

0.743 , N.S.

Original articles ${ }^{13}$ read within last 3 years (vs. earlier or never)

0.323 , N.S.

0.081, N.S.

Nagelkerke $*^{2}$ : less invasive management method vs. other methods $=0.209 ;$ MTA vs. other materials $=0.234$

${ }^{1}$ MTA mineral trioxide aggregate

${ }^{2} D P C$ direct pulp capping

${ }^{3} P P$ partial pulpotomy

${ }^{4}$ Based on the significant Pearson chi-square test, apart from variables gender and age

${ }^{5} \mathrm{OR}$ odds ratio

${ }^{6} \mathrm{CI}$ confidence interval

${ }^{7}$ N.S. non-significant

$8 * p<0.05$

${ }^{9}$ Local clinical guidelines for the management of deep carious lesions

${ }^{10}$ Summaries of international scientific articles about minimal intervention in operative dentistry in the Finnish Dental Journal

${ }^{11}$ FDS the Finnish Dental Society

${ }^{12}$ Based on the non-significant Pearson chi-square test

${ }^{13}$ Original international scientific articles about minimal intervention in operative dentistry

symptom scenario, but only typical symptoms were described for each condition of the pulp. Recent literature suggests there is a good correlation between the clinical and histologic diagnoses of the pulp [28]. However, there may have been some confusion especially regarding reversible/irreversible pulpitis scenarios. The irreversible pulpitis scenario in the questionnaire included severe spontaneous pain lasting for several minutes and lingering pain after a stimulus, but no sensitivity to percussion was mentioned. A new diagnostic system has recently been suggested for assessing pulpitis, which includes initial, mild, moderate, and severe pulpitis [29]. It is possible that the symptoms were interpreted by some respondents to indicate less severe (moderate) pulpal inflammation. That is despite the fact that spontaneous severe and/or lingering pain has been described as typical characteristics of symptomatic irreversible pulpitis, which correspond well with severe pulpitis according to the new terminology [29, 30].

Less invasive excavation methods were chosen by $64 \%$ for an asymptomatic deep carious lesion and by $77 \%$ when symptoms of reversible pulpitis were present (Table 2). According 
to these results, dentists in Finland have widely adopted the concept of prioritizing pulpal vitality when managing deep carious lesions. This is in agreement with the present international recommendations and Finland's newly published national guidelines $[20,31]$. The management preferences of dentists in Finland were in line with those of dentists in Norway [26, 27]. In contrast, studies carried out in Germany, France, Brazil, and the USA have reported 60$70 \%$ of dentists to aim at nonselective caries removal (up to hard dentine), even in the presence of an anticipated pulpal exposure during carious tissue removal $[21,22,26]$.

Vital pulp therapies were chosen by $71 \%$ for the management of an asymptomatic exposure (Table 2), which is in line with the preferences of Norwegian, German, French, and American dentists [21, 25]. In the scenario of reversible pulpitis with an exposure, vital pulp therapies were less frequently chosen by the respondents of the present study, even though recent literature suggests that reversibly inflamed pulps exposed during carious tissue removal have the potential to recover [32-34]. Moreover, only $40 \%$ of those who preferred DPC, PP, or coronal pulpotomy chose MTA as capping material, although the superiority of MTA compared to $\mathrm{CH}$ has been shown both retrospectively [33] and, recently, also in two randomized clinical studies [32, 34]. The national Finnish guidelines published in June 2016 [31] also recommend performing DPC with MTA for a pulp exposed during carious tissue removal in an adult patient, if the tooth is vital and asymptomatic, or diagnosed with reversible pulpitis. The results of this study indicate that dentists in Finland were at least partially aware of the contemporary trends in dentistry, even before national or international guidelines were published. There might be practical or financial reasons behind the preference of $\mathrm{CH}$ over MTA, as $\mathrm{CH}$-based products have been widely used for a long time and they are less expensive and easier to handle than MTA.

Controversially, in the presence of a deep carious lesion and symptoms of irreversible pulpitis, only $66 \%$ chose root canal treatment, while $25 \%$ preferred a less invasive excavation method (Table 2). This result might reflect over-optimism in the healing potential of the pulp and is not supported by the present literature. However, according to histological studies, the entire pulp is rarely irreversibly inflamed even in the case of irreversible pulpitis, but rather, the inflammation and necrotic areas are usually confined to the area adjacent to the carious exposure site [28]. Minimally invasive endodontics has recently been suggested instead of root canal treatment for the management of moderate and even severe pulpitis [29]. These management methods include partial or coronal pulpotomy, with the aim of removing only the irreversibly inflamed section of the pulp, while leaving the uninflamed pulp tissue to recover. A recent review and meta-analysis concluded that coronal pulpotomy performed either with MTA, MTA-like products, or $\mathrm{CH}$ had success rates of $88-92 \%$ in permanent teeth with closed apices after a 2-year follow-up [19]. Similar results have been reported for MTA pulpotomy, even in teeth diagnosed with irreversible pulpitis, in a recent retrospective study [35] and in a case series study [36]. In addition, a recent randomized trial comparing the performance of MTA and CH, for PP in teeth diagnosed with irreversible pulpitis, reported an $85 \%$ success rate for MTA and $43 \%$ for $\mathrm{CH}$, after 2 years [37]. Compared with root canal treatment, these management modalities are more time- and costeffective and also allow for more tooth structure to be retained, but further randomized clinical studies with longer follow-up times are needed before drawing definite conclusions.

The Nagelkerke $*^{2}$ values for the multivariable logistic regression analysis were 0.209 for the analysis of the choice of less invasive management method and 0.234 for the analysis of the choice of MTA. This indicates the models explain only about one fifth of the variation in the dependent variable; thus, the results of the analysis need to be interpreted with caution.

In the present study, a strong positive correlation was detected between the choice of a less invasive excavation strategy and employment in the public sector (Table 3). This has been observed also in a multinational questionnaire study [26]. This could be due to several factors. Plausible explanations might be locally agreed clinical guidelines and/or mandatory training generally provided by the public employers in Finland. In addition, financial considerations might affect the management decisions, although this was not expressed in the responses.

MTA was favored for DPC, PP, or coronal pulpotomy significantly more often by those who had graduated after year 1986 compared to those who had graduated earlier (Table 3). A similar Brazilian study showed the year of graduation to be the main factor affecting the management decisions [22]. However, according to the present study, different universities also seem to emphasize different management strategies. Graduation from the University of Helsinki or Turku was strongly associated with the choice of less invasive excavation strategy for a deep carious lesion, compared to graduation from other Finnish universities or from abroad.

There is a need to translate scientific evidence into clinically relevant recommendations, which often takes place through continuing education courses. In the present study, those who had attended continuing education courses in operative dentistry or endodontology by the Finnish Dental Society during last 3 years were more likely to use MTA for vital pulp therapies than those without recent training. Also, those who had agreed to local clinical guidelines preferred a less invasive excavation method for a deep carious lesion significantly more often, than those without clinical guidelines. However, no association was detected between the choice of less invasive excavation method and the use of MTA. It would be of interest to repeat the present questionnaire study to evaluate 
how the newly launched international and national guidelines have affected management preferences.

\section{Conclusion}

Less invasive treatment strategies have been adopted into the clinical practice by the majority of dentists in Finland. The use of MTA for vital pulp therapy needs to be encouraged.

Acknowledgements The authors would like to thank Dr. Hannu Vähänikkilä for his kind advice on statistical analysis.

Funding This study was supported by the Finnish Association of Women Dentists.

\section{Compliance with ethical standards}

Conflict of interest The authors declare that they have no conflict of interest.

Ethical approval This article does not contain any studies with human participants or animals performed by any of the authors.

Informed consent For this type of study, formal consent is not required, as by replying to the questionnaire each respondent showed their willingness to participate.

\section{References}

1. Marthaler TM (2004) Changes in dental caries 1953-2003. Caries Res 38(3):173-181. https://doi.org/10.1159/000077752

2. Vehkalahti M, Varsio S, Hausen H (2004) The condition of teeth (in Finnish). In: Suominen-Taipale L, Nordblad A, Vehkalahti M, Aromaa A (eds) Suomalaisten aikuisten suunterveys. Terveys 2000-tutkimus, Publications of the National Public Health Institute B16/2004. Hakapaino, Helsinki, p 77

3. Stangvaltaite L, Kundzina R, Bolstad NL, Eriksen HM, Kerosuo E (2015) Deep carious lesions and other consequences of caries among 18-year-olds at Public Dental Health Service in Northern Norway: a cross-sectional age cohort study. Acta Odontol Scand 73(6):401-407. https://doi.org/10.3109/00016357.2014.971866

4. Barton R, Wall J (1985) Fundamentals in cavity preparation. In: Sturdevant C, Barton R, Sockwell C, Strickland W (eds) The art and science of operative dentistry, 2nd edn. The C.V. Mosby Company, Missouri, pp 100-101

5. Innes NP, Frencken JE, Bjorndal L, Maltz M, Manton DJ, Ricketts $D$ et al (2016) Managing carious lesions: consensus recommendations on terminology. Adv Dent Res 28(2):49-57. https://doi.org/ 10.1177/0022034516639276

6. Bjorndal L, Reit C, Bruun G, Markvart M, Kjaeldgaard M, Nasman P et al (2010) Treatment of deep caries lesions in adults: randomized clinical trials comparing stepwise vs. direct complete excavation, and direct pulp capping vs. partial pulpotomy. Eur J Oral Sci 118(3):290-297. https://doi.org/10.1111/j.1600-0722. 2010.00731.x

7. Magnusson BO, Sundell SO (1977) Stepwise excavation of deep carious lesions in primary molars. J Int Assoc Dent Child 8(2):36-40

8. Maltz M, Garcia R, Jardim JJ, de Paula LM, Yamaguti PM, Moura MS, Garcia F, Nascimento C, Oliveira A, Mestrinho HD (2012)
Randomized trial of partial vs. stepwise caries removal: 3-year follow-up. J Dent Res 91(11):1026-1031. https://doi.org/10.1177/ 0022034512460403

9. Carvalho JC, Dige I, Machiulskiene V, Qvist V, Bakhshandeh A, Fatturi-Parolo C, Maltz M (2016) Occlusal caries: biological approach for its diagnosis and management. Caries Res 50(6):527542. https://doi.org/10.1159/000448662

10. Hoefler V, Nagaoka H, Miller CS (2016) Long-term survival and vitality outcomes of permanent teeth following deep caries treatment with step-wise and partial-caries-removal: a systematic review. J Dent 54:25-32. https://doi.org/10.1016/j.jdent.2016.09.009

11. Ng YL, Mann V, Gulabivala K (2010) Tooth survival following non-surgical root canal treatment: a systematic review of the literature. Int Endod J 43(3):171-189. https://doi.org/10.1111/j.13652591.2009.01671.x

12. Hülsmann M (2016) Epidemiology of post-treatment disease. Endod Top 34:42-63. https://doi.org/10.1111/etp.12096

13. Al-Nuaimi N, Patel S, Davies A, Bakhsh A, Foschi F, Mannocci F (2018) Pooled analysis of 1-year recall data from three root canal treatment outcome studies undertaken using cone beam computed tomography. Int Endod J 51(Suppl 3):e216-e226. https://doi.org/ 10.1111/iej.12844

14. Randow K, Glantz PO (1986) On cantilever loading of vital and non-vital teeth. An experimental clinical study. Acta Odontol Scand 44(5):271-277

15. Ou K, Chang C, Chang W, Lin C, Chang K, Huang H (2009) Effect of damping properties on fracture resistance of root filled premolar teeth: a dynamic finite element analysis. Int Endod J 42(8):694 704. https://doi.org/10.1111/j.1365-2591.2009.01570.x

16. Zelic K, Vukicevic A, Jovicic G, Aleksandrovic S, Filipovic N, Djuric M (2015) Mechanical weakening of devitalized teeth: three-dimensional Finite Element Analysis and prediction of tooth fracture. Int Endod J 48(9):850-863. https://doi.org/10.1111/iej. 12381

17. Barthel CR, Rosenkranz B, Leuenberg A, Roulet JF (2000) Pulp capping of carious exposures: treatment outcome after 5 and 10 years: a retrospective study. J Endod 26(9):525-528. https://doi. org/10.1097/00004770-200009000-00010

18. Bogen G, Kim JS, Bakland LK (2008) Direct pulp capping with mineral trioxide aggregate: an observational study. J Am Dent Assoc 139(3):305-315. https://doi.org/10.14219/jada.archive. 2008.0160

19. Alqaderi H, Lee CT, Borzangy S, Pagonis TC (2016) Coronal pulpotomy for cariously exposed permanent posterior teeth with closed apices: a systematic review and meta-analysis. J Dent 44: 1-7. https://doi.org/10.1016/j.jdent.2015.12.005

20. Schwendicke F, Frencken JE, Bjorndal L, Maltz M, Manton DJ, Ricketts D et al (2016) Managing carious lesions: consensus recommendations on carious tissue removal. Adv Dent Res 28(2):5867. https://doi.org/10.1177/0022034516639271

21. Oen KT, Thompson VP, Vena D, Caufield PW, Curro F, Dasanayake A, Ship JA, Lindblad A (2007) Attitudes and expectations of treating deep caries: a PEARL network survey. Gen Dent 55(3):197-203

22. Weber CM, Alves LS, Maltz M (2011) Treatment decisions for deep carious lesions in the Public Health Service in Southern Brazil. J Public Health Dent 71(4):265-270. https://doi.org/10. 1111/j.1752-7325.2011.00258.x

23. Schwendicke F, Meyer-Lueckel H, Dorfer C, Paris S (2013) Attitudes and behaviour regarding deep dentin caries removal: a survey among German dentists. Caries Res 47(6):566-573. https://doi.org/10.1159/000351662

24. Fink A (2014) Epidemiological field work in population-based studies. In: Ahrens W, Pigeot I (eds) Handbook of epidemiology, 2nd edn. Springer, New York, pp 577-611 
25. Stangvaltaite L, Schwendicke F, Holmgren C, Finet M, Maltz M, Elhennawy K, Kerosuo E, Doméjean S (2017) Management of pulps exposed during carious tissue removal in adults: a multinational questionnaire-based survey. Clin Oral Investig 21(7): 2303-2309. https://doi.org/10.1007/s00784-016-2023-9

26. Schwendicke F, Stangvaltaite L, Holmgren C, Maltz M, Finet M, Elhennawy K, Eriksen I, Kuzmiszyn TC, Kerosuo E, Doméjean S (2017) Dentists' attitudes and behaviour regarding deep carious lesion management: a multi-national survey. Clin Oral Investig 21(1):191-198. https://doi.org/10.1007/s00784-016-1776-5

27. Stangvaltaite L, Kundzina R, Eriksen HM, Kerosuo E (2013) Treatment preferences of deep carious lesions in mature teeth: questionnaire study among dentists in Northern Norway. Acta Odontol Scand 71(6):1532-1537. https://doi.org/10.3109/00016357.2013. 775338

28. Ricucci D, Loghin S, Siqueira JF Jr (2014) Correlation between clinical and histologic pulp diagnoses. J Endod 40(12):19321939. https://doi.org/10.1016/j.joen.2014.08.010

29. Wolters WJ, Duncan HF, Tomson PL, Karim IE, McKenna G, Dorri M, Stangvaltaite L, van der Sluis LWM (2017) Minimally invasive endodontics: a new diagnostic system for assessing pulpitis and subsequent treatment needs. Int Endod J 50(9):825-829. https:// doi.org/10.1111/iej.12793

30. Levin LG, Law AS, Holland GR, Abbott PV, Roda RS (2009) Identify and define all diagnostic terms for pulpal health and disease states. J Endod 35(12):1645-1657. https://doi.org/10.1016/j.joen. 2009.09.032

31. Root canal treatment (online). Current Care Guidelines (2016) Working group set up by the Finnish Medical Society Duodecim and the Finnish Dental Society. The Finnish Medical Society
Duodecim, Helsinki 2016. Available in Finnish: http://www. kaypahoito.fi. Accessed 28 March 2017

32. Hilton TJ, Ferracane JL, Mancl L, Northwest Practice-based Research Collaborative in Evidence-based Dentistry (NWP) (2013) Comparison of $\mathrm{CaOH}$ with MTA for direct pulp capping: a PBRN randomized clinical trial. J Dent Res 92(7 Suppl):16S22S. https://doi.org/10.1177/0022034513484336

33. Mente J, Hufnagel S, Leo M, Michel A, Gehrig H, Panagidis D, Saure D, Pfefferle T (2014) Treatment outcome of mineral trioxide aggregate or calcium hydroxide direct pulp capping: long-term results. J Endod 40(11):1746-1751. https://doi.org/10.1016/j.joen. 2014.07.019

34. Kundzina R, Stangvaltaite L, Eriksen HM, Kerosuo E (2017) Capping carious exposures in adults: a randomized controlled trial investigating mineral trioxide aggregate versus calcium hydroxide. Int Endod J 50(10):924-932. https://doi.org/10. 1111/iej.12719

35. Linsuwanont P, Wimonsutthikul K, Pothimoke U, Santiwong B (2017) Treatment outcomes of mineral trioxide aggregate pulpotomy in vital permanent teeth with carious pulp exposure: the retrospective study. J Endod 43(2):225-230. https://doi.org/10. 1016/j.joen.2016.10.027

36. Taha NA, Ahmad MB, Ghanim A (2017) Assessment of mineral trioxide aggregate pulpotomy in mature permanent teeth with carious exposures. Int Endod J 50(2):117-125. https://doi.org/10.1111/ iej. 12605

37. Taha NA, Khazali MA (2017) Partial pulpotomy in mature permanent teeth with clinical signs indicative of irreversible pulpitis: a randomized clinical trial. J Endod 43(9):1417-1421. https://doi. org/10.1016/j.joen.2017.03.033 